\title{
BIBLE TRANSLATION IN AFRICA. WHAT IMPLICATIONS DOES THE NEW UBS PERSPECTIVE HAVE FOR AFRICA? AN OVERVIEW IN THE LIGHT OF THE EMERGING NEW UBS TRANSLATION INITIA- TIVE
}

\author{
A.O. Mojola ${ }^{1}$
}

\begin{abstract}
This article gives a brief overview of the present Bible translation situation in Africa in global and historical perspective. Special focus is given to the shifts that have occurred with respect to its vision and mission and its ever widening outreach in pursuit of the Christian great commission. Shifts in the nature and types of Bible translators at different periods are looked at as well as the question of the source and receptor texts involved in the translation. The question of the various approaches to translation that have been influential receives attention with special attention being given to the dynamic- and functional-equivalent approach popularised by Eugene Nida. The rest of the paper dwells on the way forward for Bible translation in Africa in view of the influence of the past and in view of the influence of the new approaches and insights from the emerging academic field of translation studies. The recent shift in the UBS approach to translation is briefly and broadly looked at and its implication for Bible translation in Africa discussed.
\end{abstract}

\section{INTRODUCTION}

That Bible translation has enjoyed a privileged place in the history and mission of the Christian Church in Africa as elsewhere is uncontested. It is fundamental to the life and growth of the Church, to the task of theology and the need to contextualise the Christian message thus making it relevant to the needs of receptor cultures and communities. Translators are usually the first theologians in any language or community. They have to grapple with all the complex problems arising out of the need to express the ancient and eternal message of the Bible in their own language. They face the challenge of how to translate Biblical concepts, ideas, practices, festivals, rituals, spiritual beings, cultural artifacts, metaphors, beliefs, etc. in terms that make sense in the local vernacular. How to do this meaningfully, accurate-

1 Dr. A.O. Mojola, United Bible Societies Regional Translation Co-ordinator Africa Region, Nairobi, Kenya. 
ly, faithfully, clearly and with native genius and natural rhythms is the challenge that faces every translator. In so doing the translator is a pioneer who enters new territory, names it, demarcates it and thereby delimits to a certain extent the nature of biblical discourse in the local language. No wonder translation is too important to be left to translators alone!

Bible translation has since the beginning remained at the cutting edge of mission and continues to play a key role in opening up dialogue with popular cultures and with the idioms and speech of the heart as well as laying the foundations for the language of the church, of liturgy, Christian evangelism, and even of theological discourse. Indeed translation is a necessary component of Christian mission and ministry. For Professor Andrew Walls (1996) translation and incarnation are inextricably intertwined. In his article "The Translation Principle in Christian History" he writes:

Christian faith rests on a divine act of translation: "the Word became flesh, and dwelt among us" (John 1.14). Any confidence we have in the translatability of the Bible rests on that prior act of translation. There is a history of translation of the Bible because there was a translation of the Word into flesh (1996:26).

Seeing incarnation as translation underlines the necessity of making Christian discourse and practice deeply rooted in particular places and times, in particular cultures and languages, or in the linguistic and cultural practices of the ordinary person in his mundane everyday existence.

The first divine act of translation into humanity thus gives rise to a constant succession of new translations. Christian diversity is the necessary product of the Incarnation (Walls 1990; 1996:27-28).

Translation is by its very nature driven by the twin imperatives of relevance and intelligibility. It is essentially rooted in the human act and practice of communication and all that it entails.

\section{MAJOR SHIFTS IN BIBLE TRANSLATION}

\subsection{The eras of Bible translation}

The late William Smalley, a former UBS translation consultant in his seminal text Translation as mission - Bible Translation in the modern Missionary Movement (1991) makes the observation that

the history of Bible Translation is punctuated by a few great shifts when major new factors started new directions, each new era from then on running concurrently with those which began earlier. 
Smalley mentions the following epochs:

2.1 The Era of Spreading the Faith (300 BC - ) when the first major translation of the Hebrew Bible was undertaken in Alexandria, Egypt. This entailed a translation into the imperial culture and language of the time, or as some would put it a hellenisation of the faith necessarily involving what is now referred to as inculturation or contextualisation into the cultures of the Mediterranean world and of North Africa;

2.2 The Era of European Vernaculars (405 - ) inaugurated by Jerome's translation of the Scriptures into the popular language of the time the so-called Latin Vulgata. This signalled a Romanisation of the faith, an inculturation or contexualisation into the cultures and language of the new imperial Roman power. The Latin Vulgata was followed by similar others in areas where the Christian church was expanding, e.g. Georgian and Armenian, Slavonic, German, Dutch, Spanish, etc. An earlier expansion of the Christian church into North and North East Africa also created a need for new translations such as into Coptic, Ethiopic, among others;

2.3 The Era of Printing (1450 - ) which completely revolutionised the practice of writing, reading, book production and the dissemination of knowledge. Its impact on Bible translation cannot be overestimated. This new technological change reduced the costs of book production, and made it possible for many people to have access to the written word including the Word.

2.4 The Bible Society Era (1804 - ) officially inaugurated by the founding of the British and Foreign Bible Society that year. Other Bible Societies were formed following this model, among them the American Bible Society, the Netherlands Bible Society, and others. The culmination of this era was the formation of the United Bible Societies in 1946 to promote unity, co-operation and fellowship among them thus pushing their effectiveness to a new level.

2.5 Interconfessional Era (1965 - ) which coincides with the Vatican Council II of 1965. This council gave a nod to co-operation among Catholics and Christians of all confessions. Naturally this had repercussions in the era of Bible translation as well. One tangible product of this interconfessional co-operation among Catholics and other Christians was a 1968 document (revised in 1987) that laid down the guidelines and terms that would govern co-operation in Bible translating between the UBS and Catholic churches. A number of interconfessional translations guided by this document have seen the light of day and many others are ongoing. 
2.6 The Era of Non-Missionary Translation (1970 - ) which marks the change from translations largely done by non-native speakers to those largely done by native speakers. In the missionary era most translations were usually dominated by missionary translators working in foreign languages in which their competence was somewhat limited. The rise of the translations done largely or wholly by native speakers or so-called mother tongue translators marked a new shift. Smalley remarks that

over all, the balance has shifted again in considerable degree back toward people translating into their own language, with or without foreign consultants or assistance (1991:32)

\subsection{The role of the Bible translator}

Mildred Larson (1991:35) suggests four stages which mark the movement from the missionary translator to the normal model of a translator translating into his own language. These are:

3.1 The missionary translator characterises the first stage. Here the missionary translator needed to learn the target or receptor language as well as its underlying culture inevitably requiring informants/assistants/helpers indigenous to that culture. Most of the first translations in Africa were done during this period.

3.2 The missionary translator with native assistants characterises the second stage. Here the missionary translator acts as the principal translator. But realising his limitations and his inadequate grasp and command of the receptor/target language, he chooses to work with dependent or auxiliary translators. This is a kind of promotion of the earlier informants/assistants/helpers. Whereas these were in most cases illiterate, the dependent or auxiliary translators were usually literate and could in some cases be allowed to prepare a first draft translation. Decisions on the final form of the target/receptor text were invariably made by the missionary translator.

3.3 Dependent translators working in their own languages with assistance from missionary advisors/exegetes marks the third stage. Here the text is wholly translated and drafted by translators who are indigenous to the receptor/target culture and language, albeit with limited training and education. Hence their need for and dependence on missionary advisors/consultants/exegetes for the quality control of the translation. Decisions on the final form of the target/receptor text are often influenced by the input of the advisor/exegete. 
3.4 Independent translators working in their own languages marks the fourth stage. Here most of the decisions on the final form of the text are made by the translators themselves. These are mostly well trained in the required areas of specialisation. They do not accept as gospel truth the word of the missionary, missionary advisor/exegete or consultant. They are mature and informed enough to take responsibility for the quality of the final text in their language in the light of their native knowledge of their culture and language as well as their training in the required areas of specialisation. They are willing to receive technical help and advice from consultants and experts, as well as input from various groups of reviewers, etc. However the final responsibility for the text rests with them.

It is to be noted that many of the translation projects currently sponsored by the UBS here in Africa fall in the third and fourth stages while those of the pioneer period fall in the first two stages (cf. Majola 1999; Schaaf 1994; Sundkler \& Reed 2000). In 1991the legendary Dr Eugene Nida noted that:

when the United Bible Societies began, fully $90 \%$ of Bible translations in the Third World were being made by missionaries with the help of informants or translation helpers. Now in $90 \%$ of the projects the translators are nationals, and missionaries have become the resource persons (Nida 1991:5).

It is ten years or so since Dr. Nida wrote these words. The situation has definitely changed often for the better. This means that this percentage has gone up. It could be observed that the Wycliff Bible Translators who are on whole lagging behind in this area, are making belated attempts to improve things. In fact in some countries such as Kenya there is less dependence on the missionary translator. First speakers of the language are now in charge of making decisions on their translations as well as on their final form.

\subsection{The role of the source text and source language}

Another widely acknowledged distinction is that between translations where the translators work directly from the original language source texts and those translations where the translators work from other translated texts or versions of the Bible in related or unrelated languages. It is interesting to note that most of the existing translations in Africa were not based on the original language source texts, i.e. the Hebrew, Greek and Aramaic original source texts, but on other translations in the major languages of the colonial powers. These are so to speak translations of transla- 
tions! For many translators working from the English texts, the King James Version, the Authorised Version or the Revised Standard Version have served as their window into the original texts. For those working from the French texts the Segond, the Segond Revisee or the Traduction Oecuménique de la Bible $(T O B)$ have played a similar function. As the quality of African translators has improved they have supplemented these literal and so-called formal correspondence translations with some limited reference to the Hebrew or the Greek texts especially in problematic or difficult passages. Comparison with other translations in the colonial languages or those in related languages has contributed to influencing decisions as to the meaning of the texts in question or even as to their correct interpretation.

This is certainly a factor that affects fidelity to the original Hebrew or Greek source texts. There is no doubt that working directly from the Hebrew or Greek texts into the African languages and cultures is preferable to getting what the Hebrew or Greek texts say via the secondary medium of English, French, German or any other secondary texts. Moreover the closeness of African languages and cultures to those of the Judeo-Christian world, or to the world of ancient Israel or early Christianity makes direct mediation the preferred option in translation. Going via a third language and culture such as the Indo-European English or French introduces problems and elements that may not be present in the original texts (cf. Sanneh 1989). The main point here is the view that it should be a requirement in the third millennium for African translators of the Holy Scriptures to master and work directly from the ancient languages in which the Christian Holy Scriptures were originally written. Similarly it should be a requirement for African Christian Biblical scholars, exegetes, theologians and expositors of the third millennium to be competent in the use of these Biblical languages. This is necessary for authentically engaging the exegetical and hermeneutical task in Africa directly from the original source texts, languages, and cultures and in terms of the receptor African languages, cultures and traditions without the mediation of the Indo-European languages, cultures and value systems. Indeed the widespread introduction and teaching of Biblical languages in African Bible schools, theological colleges, and Christian institutes of higher learning needs to become common place. This may be one of the factors necessary to facilitate and encourage a wider reading of the original texts and the creation of good quality translations that directly engage the ancient text world and language. It is interesting to note that ancient Hebrew belongs to the Afro-Asiatic language family, the majority of whose members are in fact African languages! The implication of the above and its possible impact on African Christianity urgently needs a rethinking. 


\subsection{The emergence of theoretical approaches to translation}

The emergence of a UBS approach to translation owes much to the work and writings of Eugene Nida. Smalley (1991:28) notes:

The promotion of professional expertise, the development of translation theory and of translation procedures based on such theory, began when Eugene A. Nida joined the American Bible Society staff in 1943.

He adds:

Up to that time the Bible Societies had given what advice they could to translators, and had sought to ensure the value and quality of each translation as well as they knew how, but had no developed and articulated theoretical base for doing so.

Nida apart from reinventing, renaming and popularising the old theory of sense for sense translation, may be said to have also promoted the idea of a team of full time translation consultants, employed and paid by the Bible Societies to offer expert help and advice to translation projects. These were all required to meet the highest academic global standards in the areas of linguistic or Biblical studies and sometimes anthropology. Nearly all the pioneer translation consultants, all possessing a Ph.D. in their areas of expertise were recruited by Nida himself. He provided exemplary personal leadership to this international team as well as embodying in his practice a model of this role, placing a premium on scholarship and research. Smalley summarises this as follows:

Nida as a linguist and anthropologist as well as student of ancient Greek literature, quickly proceeded to amass the necessary data and develop ways of conceptualising the process of translation. In time he also recruited a professional team of linguists and Biblical scholars to serve with him as consultants to translators all over the world. Later they would be internationalised, working under the auspices of the United Bible Societies (1991:28).

The UBS approach is usual closely associated with the writings of Nida and his colleagues. Among Nida's more prominent colleagues and collaborators are the following — William Wonderly, William Smalley, William Reyburn, Robert Bratcher, Jacob Loewen, Jean-Claude Margot, Charles Taber, Barclay Newman, Rudolf Kassulke and Jan de Waard. Their writings have become the basis for the theory of translation that has come to be known as dynamic equivalence or functional equivalence. This theory is contrasted with that usually referred to as the formal correspondence approach to translation. Perhaps this theory would not have been so influential among 
translators and widely applied in other world languages had it not been for a number of very popular versions sponsored by some major western Bible Societies. The first to appear was the Spanish Version Popular. This was followed by publication of others such as Today's English Version, the French common language translation Français Courant, the German Die Gute Nachricht. These common language versions of the Bible translated under the leadership of Nida and in application of his theory have since then been viewed not only as incarnations of the theory of dynamic equivalence translation but also as models that others could imitate. It is not surprising that in a number of cases translators simply translated or followed these models.

The writings of Nida and his colleagues and collaborators contributed a great deal to current widespread practice by many translators to think of translation mainly in terms of the age-old distinction between word for word vs. sense for sense translation or in Nida's terminology between formal correspondence vs. dynamic equivalence translation. Most translators tend to see translations as either one or the other. This way of categorising translations is nowadays seen by a number of translation scholars as simplistic and inadequate. In recent times alternative distinctions have been suggested, for example those distinguishing between overt vs. covert translation (Juliane House), between foreignising vs. domesticating translation (Lawrence Venuti), between linguistic vs. literary (James Holmes), between literal vs. idiomatic (Beekman \& Callow), semantic vs. communicative (Newmark), form-based vs. meaning-based (Larson), documentary vs. instrumental (Nord), direct vs. indirect (Gutt), observational vs. participative (Pym), among others.

The rise of translation studies as a major discipline of research and study in universities everywhere has led to a re-examination of a wide range of issues in translation that were usually taken for granted, such as the above distinctions. Further the cross-disciplinary or multi-disciplinary perspective of translation studies means that the monopoly or academic hegemony of linguistics as the only or even major discipline on which translators depend on or draw from is no more. Nida's work was in many ways a precursor to these new developments. Nowadays work in translation draws on a wide range of disciplines, among them social and cultural studies, literary theory and comparative literature, communication studies, philosophy, psychology, etc. A key feature of this development is that translation can now be viewed from a multiplicity of perspectives. There is now no one correct way of doing translation. Translators now have to contend with "a plethora of available theoretical frameworks and approaches" (see Mojola in Wilt 2002). While this is clearly not the place to describe these, it is in order to 
give mention to some of the major contemporary trends - such as the traditional linguistic approaches, the literary approaches that include the discourse and register analysis approaches of Hatim and Mason (Hatim 2001), the functional and communicative approaches such as those of Katharina Reiss, Hans Vermeer, Christian Nord; the descriptive and systemic approaches such as those of Israeli scholars Itamar Even-Zohar and Gideon Toury or the Dutch and Flemish scholars Theo Hermans, Andre Lefevere or Jose Lambert; semiotic approaches; interpretive approaches such as those M. Lederer, Seleskovitch or Delisle or the post-colonial approaches such as those of Tejaswini Niranjana, Oswald de Andrade or Maria Tymoczko (cf. Munday 2001).

In the current interdisciplinary environment within which translation studies and translation practice find themselves, it seems prudent and pragmatic to listen to the wide variety of voices on translation rather than opt for a particular perspective or exclusive approach to Bible translation. Nowadays Bible translation has to take into account a wide variety of factors and interests in Bible Society sponsored translation projects — such as cultural difference in the target language, socio-linguistic factors including those of language variety or dialect difference, gender issues, social status, educational level, population and demographic factors, age group factors, ideological orientation, confessional or denominational issues relating to doctrine or power, economic factors related to the translation and publishing process, issues of literacy and language planning, liturgical and Scripture use practices, life concerns and needs of the various audience groups, among others. A prescriptive approach in this kind of context is likely to prove unhelpful. A wide variety of perspectives, approaches and tools are therefore needed to help assess Scripture needs and the contexts of intended use, the diversity of target audiences and their possible response to types of possible Scripture translations, levels, formats, etc. These challenges call for greater sensitivity on the part of translators and other staff involved in the translation process. The need for translators and their collaborators, Bible Society staff, church groups and other partner organisations involved in this task as well as others to respond effectively and efficiently to meet these needs goes without saying.

\section{CONCLUSION}

The emerging new UBS approach to translation is eclectic in the above sense - drawing on the wisdom and experience of the past but also open to the voices and insights of translation scholars and researchers in academia or within its ranks. There does not as yet appear to be any preference for any 
particular approach or perspective. Even though there is a predilection for a certain functionalism that has its roots in Nida's legacy, there is on the whole an openness to learn and to glean applicable and appropriate insights from whatever source. The overriding objective of the UBS as defined for example in the Mississauga Document (1996) is "to provide Scriptures that meet human needs for the ministry of the churches for worship, nurture, service, and evangelism", and in support of this objective the related objective "to undertake research and information gathering activities to provide an informed basis for the programs and activities of the Bible Societies".

These objectives were further affirmed by the UBS World Assembly meeting in South Africa, at Midrand in October 2000. The UBS Direction from Midrand document (2000) reaffirmed the common task of achieving "the widest possible, effective and meaningful distribution of the Holy Scriptures helping people to interact with the Word of God". This was seen to call for a commitment to produce Scriptures in relevant and appropriate formats, create new Scripture products that encourage people to understand and engage personally with Scripture, and that speak directly to human needs and concerns leading to engagement or encounter with God's Word, address the needs of non-literate people and new readers, make wise use of technological developments to better fulfil our task. The Midrand Assembly declared that these were to be done on the basis of co-operation with all churches and Christian confessions, sharing of resources, skills, gifts, insight, experience and finance, locally through churches, Christian organisations or individuals working in partnership with each Bible Society or globally through the UBS fellowship and her member societies on the basis of integrity, accountability and transparency.

The emerging UBS perspective on translation hinted to above is inextricably linked to the contexts in which the Bible Societies operate and to the policy directives and guidelines that provide the framework for both their local and international work. Any translation theory or approach developed for use within the UBS fellowship that does not take account of these directives and guidelines or address itself to the needs of the intended audiences served by the local Bible Society or fellowship would certainly be doomed to failure right from the outset. At the UBS Triennal Translation Workshop held in Malaga, Spain in June 2000 an attempt was made to think through the implications of such an approach. The emerging approach from this consultation is broadly interdisciplinary/multi-disciplinary and is expected to provide guidelines to all translators in the fellowship. Africa has played and continues to play a key role in the development of this emerging approach. Naturally translators in Africa as elsewhere are 
expected to benefit from its insights. The new approach pays more attention on the communication process and its complexities in all its diversity, as well as on its application to the translation process. Furthermore the question of quality translator training of local mother tongue speakers/ translators as well as other staff contributing to the translation process is given top priority in this framework. To do this is to take seriously the obvious observation that a translation is only as good as the level and quality of its translator/s. Access to and use of modern computers especially by translators is strongly encouraged as this contributes greatly to facilitating translation quality and time saving. Use of empirical research and data with respect to sociolinguistic variables and language/dialect data, or market research and data with respect to the demographics and needs of the target audiences is basic to translation relevance and effectiveness. These cannot be ignored by translation teams or Bible Societies in Africa or elsewhere.

The UBS meeting in Mississauga in 1996 spoke of the "unfinished task" that is the current challenge of Bible Society work. The meeting at Midrand spoke of the need to be "at the cutting edge" in our attempt to meet the challenges of the unfinished task. The task of translating the Scriptures in African languages or dialects, as in others as well is basic and primary in this unfinished mission. However to meet this task more effectively, the level, quality, skills, training, tools, approaches, methodologies, etc. of translation workers will need to be at the cutting edge. Moreover their level of commitment to the task, their sense of call, their motivation, their stamina, etc are not irrelevant factors.

\section{BIBLIOGRAPHY}

\section{HАTIM B}

2001. Teaching and researching translation. Harlow Essex: UK: Pearson Education Ltd.

\section{LARSON M}

1991. Indigenizing of translation process: the SIL perspective. The Bible Translator 42A:34-41.

Mojola A O

1999. God speaks in our own languages — Bible translation in East Africa 18441998. Nairobi: Bible Societies. 
MUNDAY J

2001. Introducing translation studies - theories and applications. London/New York: Routledge.

NiDA E A

1991. Trends in Bible translating within the United Bible Societies: an historical perspective. The Bible Translator 42A:2-5.

\section{SANNEH L}

1989. Translating the message — the missionary impact on culture. Maryknoll New York: Orbis Press.

\section{SCHAAF Y}

1994. On their way rejoicing — The history and role of the Bible in Africa. Carlisle UK: Paternoster Press.

\section{SMALLEY W A}

1991. Translation as mission - Bible translation in the modern Missionary Movement. Macon Georgia: Mercer University Press.

STINe P C (ed.)

1990. Bible Translation and the spread of the church - the last 200 years. Leiden: E. J. Brill.

\section{SUNDKLER B \& REED C}

2000. A history of the church in Africa. Cambridge: Cambridge University Press.

\section{WALLS A}

1990. The translation principle in Christian history. In: Stine 1990:24-39.

\section{Walls A F}

1996. The Missionary Movement in Christian history — studies in the transmission of faith. Maryknoll New York: Orbis Books/ Edinburgh: T\&T Clark.

WILT T (ed.)

2000. Bible translation: frames of reference. Manchester: St. Jerome.

Keywords

Bible translation

Africa

History

United Bible Societies 